\title{
Isolation and Some Properties of an Aspartate Aminotransferase Inhibitor, Gostatin
}

\author{
Toyokazu Nishino and Sawao MURAo \\ Department of Agricultural Chemistry, College of Agriculture, \\ University of Osaka Prefecture, Sakai, Osaka 591, Japan
}

Received December 9, 1982

\begin{abstract}
A novel aspartate aminotransferase inhibitor named gostatin was isolated as crystals from the culture filtrate of Streptomyces sumanensis NK-23. The structure has been established to be 5amino-2-carboxy-4-oxo-1,4,5,6-tetrahydropyridine-3-acetic acid by X-ray crystallographic analysis (K. Ibata et al., manuscript in preparation). The results of chemical and instrumental analyses of the inhibitor are described in this paper.

Gostatin showed time-dependent inhibitory action against aspartate aminotransferases and alanine aminotransferase. Both pyridoxal phosphate- and pyridoxamine phosphate-linked enzymes were sensitive to the inhibitor.
\end{abstract}

A novel cyclic amino acid named gostatin, produced by Streptomyces sumanensis NK-23, shows a strong inhibitory activity against aspartate aminotransferases (EC 2.6.1.1, GOT)* of various origins. ${ }^{1,2)}$ This inhibitor was isolated as crystals and the structure was determined to be 5-amino-2-carboxy-4-oxo-1,4,5,6tetrahydropyridine-3-acetic acid (Fig. 1) by Xray crystallographic analysis $(\mathrm{K}$. Ibata et al., manuscript in preparation).

In this paper, the isolation and some chemical and biochemical properties of gostatin are reported.

\section{MATERIALS AND METHODS}

Microorganism and culture conditions. Streptomyces sumanensis NK-23, which was isolated from soil by the authors, ${ }^{1,2)}$ was used in this experiment. The strain was cultured under the optimum conditions for the production of gostatin in a Marubishi MSJ-U2 jar fermentor. ${ }^{2)}$ The culture filtrate at $114 \mathrm{hr}$ cultivation was used for the preparation of the inhibitor.

Assay of gostatin activity. Gostatin activity was assayed by the method described in the previous paper. ${ }^{2)}$

Isolation of gostatin. The isolation procedure reported in the previous paper was modified. ${ }^{1)}$ The culture filtrate (35 liters) was adjusted to $\mathrm{pH} 4.0$ with formic acid, and activated charcoal $(2 \%$, w/v) was added. After the mixture stood for $30 \mathrm{~min}$, the non-adsorbing fraction was collected by filtration. This solution was applied onto a column $(10 \times 35 \mathrm{~cm})$ of Dowex $1 \times 4$ (formate type, 100 200 mesh) previously equilibrated with $50 \mathrm{~mm}$ ammonium formate-formic acid buffer ( $\mathrm{pH} 4.0)$. Gostatin was weakly adsorbed to the column and eluted with $50 \mathrm{~mm}$ ammonium formate-formic acid buffer ( $\mathrm{pH} 4.0$ ). Active fractions thus obtained (36 liters) were then applied onto a column ( $10 \times$ $35 \mathrm{~cm})$ of Dowex $1 \times 4(\mathrm{OH}$ type, $100 \sim 200 \mathrm{mesh})$ and eluted with $0.5 \mathrm{M} \mathrm{NH}{ }_{4} \mathrm{Cl}$ solution. The fractions containing gostatin were pooled (14 liters), evaporated in vacuo to dryness and dissolved in a minimum volume of water $(1150 \mathrm{ml})$. After the solution was adjusted to $\mathrm{pH} 4.0$ with $6 \mathrm{~N} \mathrm{HCl}$, methanol was added at a final concentration of $50 \%(\mathrm{v} / \mathrm{v})$ and the precipitate was removed by filtration. Gostatin was precipitated from the supernatant by adding ethanol at a final concentration of $60 \%$ and allowing the mixture to stand overnight. The precipitates were collected by centrifugation $(10,000 \times g, 10 \mathrm{~min})$ and dissolved in $170 \mathrm{ml}$ of water. Gostatin was crystallized from this solution by adjusting the $\mathrm{pH}(\mathrm{pH} 4.0)$ and adding methanol.

Instrumental analysis. Instrumental analysses were performed using the following instruments: IR, a Hitachi 26010 infrared spectrometer; UV, a Hitachi 320 spectrophotometer; optical rotation, a JASCO DIP-SL polarimeter; mass spectrum, a Hitachi RMU-7M spectrometer in the electron impact method; ${ }^{1} \mathrm{H}$ and ${ }^{13} \mathrm{C}$ NMR spectra, a JEOL FX-200 spectrometer.

Abbreviations: GOT, aspartate aminotransferase; GPT, alanine aminotransferase; PLP, pyridoxal 5'-phosphate; PMP, pyridoxamine 5'-phosphate; DMSO, dimethylsulfoxide; TMS, tetramethylsilane. 


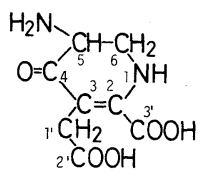

FIG. 1. Structure of Gostatin.

5-Amino-2-carboxy-4-oxo-1,4,5,6-tetrahydropyridine-3acetic acid.

Thin-layer chromatography and paper electrophoresis. Thin-layer chromatography was carried out using cellulose plates (Merck) with the following solvent system: (A), isopropanol- $\mathrm{NH}_{4} \mathrm{OH}-\mathrm{H}_{2} \mathrm{O}(6: 1: 2)$; (B), $n$-butanolacetic acid- $\mathrm{H}_{2} \mathrm{O} \quad(4: 1: 2) ; \quad(\mathrm{C})$, tert-butanol-formic acid- $\mathrm{H}_{2} \mathrm{O}(70: 50: 15)$; (D), water saturated [ $n$-butanolpyridine (2:1)]; (E), isobutanol-acetic acid- $\mathrm{H}_{2} \mathrm{O}(2: 1: 2)$. Paper electrophoresis was performed with the potential gradient of $20 \mathrm{~V} / \mathrm{cm}$ for $1 \mathrm{hr}$ in $50 \mathrm{~mm}$ acetate buffer (pH 5.0)

Assay system for determination of inhibition specificity. Test enzymes were preincubated with gostatin in $50 \mathrm{~mm}$ Tris-HCl buffer, pH 8.5 (for GOT and GPT), $50 \mathrm{~mm}$ potassium phosphate buffer, $\mathrm{pH} 7.0$ (glutamate decarboxylase and $\gamma$-aminobutylate aminotransferase), $0.2 \mathrm{M}$ Trismaleate buffer, $\mathrm{pH} 6.8$ (phosphorylase), $40 \mathrm{~mm}$ imidazole buffer, pH 7.0 (glutamine synthetase) or $0.1 \mathrm{M}$ Tris- $\mathrm{HCl}$ buffer, pH 7.9 containing $10 \%$ glycerol (glutamate dehydrogenase). GOT (cytosolic enzyme of pig heart and wheat germ) and GPT were assayed by the method of Yatzidis $^{3)}$ and mitochondrial GOT of pig heart was assayed in a system coupled with malate dehydrogenase and NADH. ${ }^{4)}$ Glutamate decarboxylase activity was determined in a Warburg apparatus. ${ }^{\text {5) }}$

Phosphorylase activity was assayed according to Cori et al., ${ }^{6)}$ and glutamine synthetase was assayed by the determination of production of $\gamma$-glutamylhydroxamate. ${ }^{7)}$ Glutamate dehydrogenase was assayed by the method of Fahien et al., ${ }^{8)}$ and $\gamma$-aminobutylate aminotransferase was assayed in a system coupled with succinic semialdehyde dehydrogenase. ${ }^{9)}$

Enzymes. Mitochondrial GOT (pig heart) was kindly donated by Dr. H. Wada (Osaka University Medical School). Wheat germ GOT was prepared by the method of Verjee et al.$^{10)}$ Cytosolic GOT (pig heart), phosphorylase a (rabbit muscle), glutamate dehydrogenase (beef liver), $\gamma$ aminobutylate aminotransferase (Pseudomonas fluorescens) and GPT (pig heart) were purchased from Boehringer Mannheim. Glutamate decarboxylase (type V, Escherichia coli) and glutamine synthetase (ovine brain) were obtained from Sigma Chemical Co. Malate dehydrogenase was purchased from Oriental Yeast Co. Transaminases were used after being treated with 2oxoglutarate and dialysis. Holo GOT in pyridoxamine form was prepared by the method of Jenkins et al. ${ }^{11)}$

\section{RESULTS}

\section{Isolation of gostatin}

A summary of the purification of gostatin from a 35 liters culture filtrate of $S$. sumanensis is shown in Table I. After being recrystallized from aqueous methanol, the total yield was $1900 \mathrm{mg}$, and colorless needles were obtained. This preparation gave a single spot (with $I_{2}$ vapor and ninhydrin) on thin-layer chromatography and paper electrophoresis: $R f$ values, 0.17 (A), 0.22 (B), 0.58 (C), 0.08 (D), 0.51 (E); mobility, $+3.5 \mathrm{~cm}(\mathrm{PLP},+4.6 \mathrm{~cm})$.

\section{Chemical properties of gostatin}

Physical and chemical properties of gostatin are summarized in Table II. The molecular formula of gostatin is $\mathrm{C}_{8} \mathrm{H}_{10} \mathrm{O}_{5} \mathrm{~N}_{2}(\mathrm{MW}=$ 214.17) and was confirmed by mass spectrometry of the tetratrimethylsilyl ester $\left(\mathrm{M}^{+}, \mathrm{m} / z\right.$ 502). Gostatin is an amphotheric compound $\left[\mathrm{p} K_{\mathrm{a}} \approx 1.5,4.84\right.$ and 8.13, titration equivalent (found) 216] and it is adsorbed to an anion exchange resin (Dowex 1) in alkaline $\mathrm{pH}$ and to a cation exchange resin (Dowex 50W) in acidic $\mathrm{pH}$. Gostatin showed a positive color reaction with ninhydrin. The IR spectrum is shown in Fig. 2. It suggested the presence of an amino group $\left(\mathrm{NH}_{3}{ }^{+}, 3285\right.$ and $\left.1520 \mathrm{~cm}^{-1}\right)$ and a carboxyl group (COOH, 3500-2600 and 1725; $\left.\mathrm{COO}^{-}, 1388\right)$. The UV spectra are shown in Fig. 3. $\lambda_{\max }^{\mathrm{pH} 7} \mathrm{~nm}(\varepsilon): 331(10,000)$. $\lambda_{\max }^{0.1 \mathrm{~N} \mathrm{HCl}}: 343$ (7470). $\lambda_{\max }^{0.1 \mathrm{~N} \mathrm{NaOH}}: 330$ (9170). These properties suggested that gostatin was a novel amino acid. ${ }^{1} \mathrm{H}$ NMR spectrum was measured in DMSO- $d_{6}$ at $200 \mathrm{MHz}$ and $50^{\circ} \mathrm{C}$. After the structure determination by X-ray crystallographic analysis, the resonances were assigned as follows: $\delta_{\text {TMS }}^{\text {DMSO-d }} 3.1 \sim 3.3(3 \mathrm{H}, \mathrm{m}$, $\left.1^{\prime}-\mathrm{H}, 6-\mathrm{H}\right), 3.6 \sim 3.7 \quad(2 \mathrm{H}, \mathrm{m}, 5-\mathrm{H}, 6-\mathrm{H})$, $5.5 \sim 6.3\left(4 \mathrm{H}\right.$, br, $\left.-\mathrm{NH}_{3}{ }^{+}, \quad, \mathrm{NH}\right), 7.1 \sim 7.4$ (1H, br, $\mathrm{COOH})$.

The natural-abundance ${ }^{13} \mathrm{C}$ NMR spectrum of gostatin, measured in DMSO- $d_{6}$ at $50 \mathrm{MHz}$, contains resonances ascribable to 8 carbon atoms (Table III). The three resonances at higher field were identified as 5-C, 6-C and 1'$\mathrm{C}$ with the aid of the off resonance proton 
TABle I. Summary of Isolation of Gostatin

\begin{tabular}{|c|c|c|c|c|c|}
\hline Treatment & $\begin{array}{l}\text { Volume } \\
\text { (ml) }\end{array}$ & $\begin{array}{c}\text { Inhibitory } \\
\text { activity } \\
\text { (units) } \times 10^{3}\end{array}$ & $\begin{array}{l}A_{330} \\
\times 10^{3}\end{array}$ & $\begin{array}{c}\text { Specific } \\
\text { activity } \\
\text { (units } / A_{330} \text { ) }\end{array}$ & $\begin{array}{c}\text { Recovery } \\
(\%)\end{array}$ \\
\hline Culture filtrate & 35,000 & 13,900 & 1580 & 8.8 & 100 \\
\hline Activated charcoal & 33,200 & 15,100 & 413 & 36.6 & 109 \\
\hline Dowex $1 \times 4$ (formate) & 36,000 & 14,000 & 355 & 39.4 & 101 \\
\hline Dowex $1 \times 4\left(\mathrm{OH}^{-}\right)$ & 14,000 & 13,200 & 288 & 45.8 & 95 \\
\hline Ethanol ppt. & 170 & 7,790 & 169 & 46.2 & 56 \\
\hline Crystallization & 100 & 5,990 & 126 & 47.5 & 43 \\
\hline Recrystallization & $\begin{array}{l}1900 \\
(\mathrm{mg})\end{array}$ & 4,130 & 86 & 48.0 & 30 \\
\hline
\end{tabular}

Table II. Some Chemical Properties of Gostatin

\section{Elemental analysis}

Found: C, 41.86; H, 5.03; N, 12.10

Calcd for $\mathrm{C}_{8} \mathrm{H}_{10} \mathrm{O}_{5} \mathrm{~N}_{2} \cdot \mathrm{H}_{2} \mathrm{O}: \mathrm{C}, 41.58 ; \mathrm{H}, 5.23$;

N, $12.12 \%$.

Mass spectrum

$502\left(\mathrm{M}^{+}\right.$, tetratrimethylsilyl-derivative)

$[\alpha]_{\mathrm{D}}^{16}-117^{\circ}\left(c=1.0,2 \mathrm{M} \mathrm{NH}_{4} \mathrm{OH}\right)$

Color reaction $^{a}$

Ninhydrin, $+; \mathrm{I}_{2}$ vapor, + ; potassium permanganate,

+; ferric chloride, +; Rydon-Smith, -; Elson-

Morgan, -; Morgan-Elson, -; phenol sulfate, - ;

2,4-dinitrophenyl hydrazine, - .

Solubility

Soluble in water and DMSO. Slightly soluble in methanol. Insoluble in ethanol, ethyl ether, benzene, chloroform, and ethyl acetate.

$\mathrm{p} K_{\mathrm{a}} \approx 1.5,4.84,8.13 ;$ titration equivalent $=216$ (found)

Melting point

No definite mp.

$a+$, positive; - , negative.

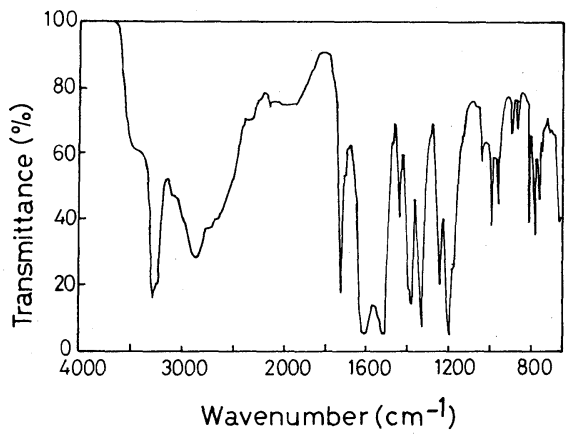

FIG. 2. Infrared Spectrum of Gostatin in $\mathrm{KBr}$ Disk.

decoupling method. The five resonances of quaternary carbons were also assigned by

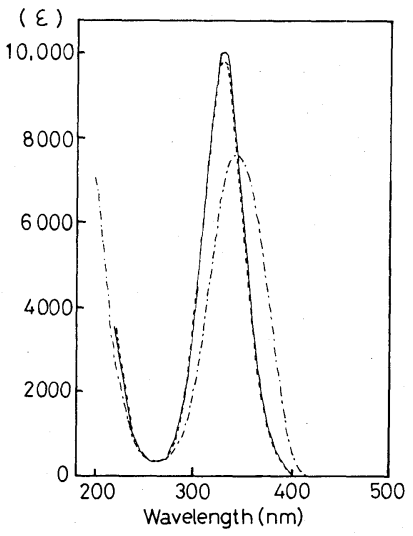

FIG. 3. UV Spectra of Gostatin.

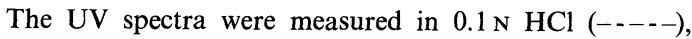
$0.1 \mathrm{M}$ potassium phosphate buffer, $\mathrm{pH} 7.0$ (-) and $0.1 \mathrm{~N}$ $\mathrm{NaOH}(-----)$.

Table III. Carbon-13 NMR Chemical Shifts OF Gostatin (IN DMSO- $d_{6}$ AT $50 \mathrm{MHz}$ )

\begin{tabular}{cc}
\hline Carbon $^{a}$ & Chemical shift $^{b}$ \\
\hline 6 & 32.1 \\
$1^{\prime}$ & 44.2 \\
5 & 50.5 \\
3 & 97.8 \\
2 & 159.5 \\
$3^{\prime}$ & 165.6 \\
$2^{\prime}$ & 172.9 \\
4 & 187.9
\end{tabular}

a Numbering of carbon atoms are shown in Fig. 1.

${ }^{b}$ Chemical shifts are expressed by the $\delta$-value (ppm) from internal TMS reference.

comparison of chemical shifts with those of model compounds. ${ }^{12,13)}$

The $\mathrm{pH}$ and thermal stabilities of gostatin 
TABLE IV. INhibition SPECtrum OF Gostatin

The enzymes were preincubated with gostatin under the indicated conditions and then residual enzyme activities were assayed. See MATERIALS AND Methods for details.

\begin{tabular}{cccc}
\hline Enzyme (origin) & $\begin{array}{c}\text { Preincubation } \\
\text { conditions } \\
\min \left({ }^{\circ} \mathrm{C}\right)\end{array}$ & $\begin{array}{c}\text { Gostatin } \\
\text { concn. } \\
(\mu \mathrm{M})\end{array}$ & $\begin{array}{c}\text { Inhibition } \\
(\%)\end{array}$ \\
\hline $\begin{array}{c}\text { GOT (pig heart, mit) } \\
\quad \text { (pig heart, cyt) }\end{array}$ & $10(37)$ & 4 & 100 \\
$\quad 10(37)$ & 4 & 95 \\
$\begin{array}{c}\text { GPT (pig heart) } \\
\gamma \text {-Aminobutylate } \\
\text { aminotransferase } \\
\quad \text { Pseud. fluorescens) }\end{array}$ & $10(37)$ & 4 & 52 \\
$\begin{array}{c}\text { Glutamate decarboxylase } \\
\quad \text { Escherichia coli) }\end{array}$ & $10(37)$ & 20 & 0 \\
$\begin{array}{c}\text { Glutamate dehydrogenase } \\
\text { (bovine liver) }\end{array}$ & $30(25)$ & 20 & 0 \\
Phosphorylase A \\
$\quad$ (rabbit muscle) \\
$\begin{array}{c}\text { Glutamine synthetase } \\
\text { (ovine brain) }\end{array}$ & $30(37)$ & 20 & 0 \\
\hline
\end{tabular}

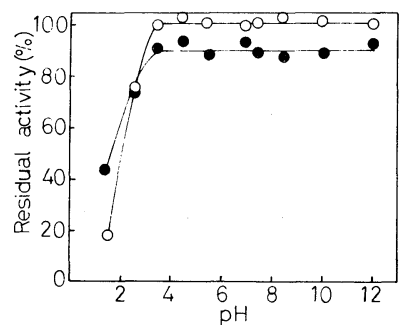

FIG. 4. pH and Thermal Stability of Gostatin.

Gostatin was incubated at $37^{\circ} \mathrm{C}$ for $22 \mathrm{hr}$ and at $100^{\circ} \mathrm{C}$ for $10 \mathrm{~min}$ in various buffers and then residual activity was determined. Buffer system used was $0.1 \mathrm{M}$ acetate- $\mathrm{HCl}$ buffer ( $\mathrm{pH} 1.5 \sim 3.5), 0.1 \mathrm{M}$ acetate buffer $(4.5 \sim 5.5), 0.1 \mathrm{M}$ potassium phosphate buffer $(6.5 \sim 7.0), 0.1 \mathrm{M}$ Tris- $\mathrm{HCl}$ buffer (7.5 8.5), $0.1 \mathrm{M}$ glycine- $\mathrm{NaOH}$ buffer (10) and $0.01 \mathrm{~N} \mathrm{NaOH}$. Open symbols, treatment at $37^{\circ} \mathrm{C}$; closed symbols, $100^{\circ} \mathrm{C}$.

were determined. The inhibitor $(0.1 \mathrm{mg})$ was dissolved in various buffers and kept at $37^{\circ} \mathrm{C}$ for $22 \mathrm{hr}$ and $100^{\circ} \mathrm{C}$ for $10 \mathrm{~min}$, and then residual activity was assayed. As shown in Fig. 4, gostatin was unstable below pH 3.0.

\section{Inhibitory action against various enzymes}

The effect of gostatin on various PLP-linked aminotransferases and other enzymes are summarized in Table IV. Pig heart GOTs (mito-

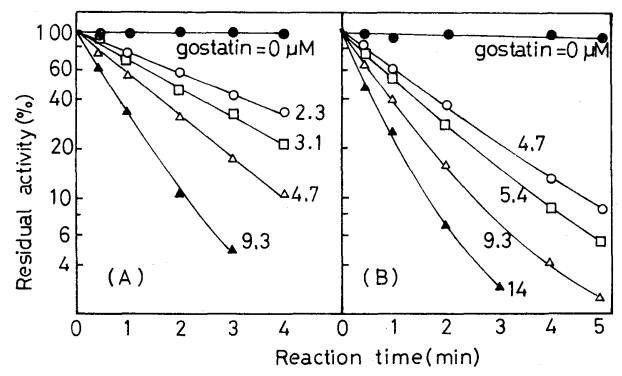

FIG. 5. Time-Dependent Inactivation of GOT in PLP and PMP Form.

PLP (0.03 unit) and PMP (0.025 unit)-linked GOT (pig heart, mitochondrial) were incubated with the indicated concentration of gostatin at $25^{\circ} \mathrm{C}$ in $50 \mathrm{~mm}$ potassium phosphate buffer ( $\mathrm{pH} 7.0$ ). At various time points, residual enzyme activities were assayed in the assay system coupled with malate dehydrogenase and NADH. (A), PLP-linked enzyme; (B), PMP-linked enzyme.

chondrial and cytosolic) were strongly inhibited, and wheat germ GOT and GPT (pig heart) were less effectively inhibited. In addition to these enzymes, gostatin also inhibits yeast kynurenine aminotransferase $(76 \%$ inhibition after $10 \mathrm{~min}$ incubation at $\left.30^{\circ} \mathrm{C}\right) .{ }^{14}$ ) The inhibitor, however, showed no inhibitory activity against the other pyridoxal-phosphate-dependent enzymes so far tested, such 
as $\gamma$-aminobutylate aminotransferase, glutamate decarboxylase or phosphorylase.

Gostatin inhibits GOT in both pyridoxal and pyridoxamine forms. Figure 5 shows the time course of inactivation of PLP and PMPlinked GOT by gostatin. Pyridoxamine-linked enzyme showed almost the same sensitivity as that of pyridoxal-linked enzyme. Gostatin required preincubation with the enzyme for its inhibitory action (Fig. 5) and in the presence of substrates it shows no inhibitor activity even against the susceptible enzymes.

\section{DISCUSSION}

Certain chemical properties of gostatin, such as the $\mathrm{p} K_{\mathrm{a}}$, color reaction with ninhydrin<smiles>NC(CNC(C(=O)O)=C(CC(=O)O)C(=O)O)C(=O)O</smiles>

[gostatin]

Gostatin is a time-dependent irreversible inhibitor of GOT (Fig. 5 and our preliminary experiments) and is considered to be a mechanism-based inhibitor (suicide substrate). ${ }^{15 \sim 18)}$ GOT inhibitors having similar properties have been obtained. These involve $\beta, \gamma$-unsaturated amino acids such as 2-amino4-methoxy-trans-3-butenoic acid, allyl chloride and sulfates such as $\beta$-chloroalanine, an acetylenic substrate analog (propagylglycine), and compounds containing an isoxazolidine ring such as cycloglutamate. ${ }^{15,17,19 \sim 21)}$ Gostatin is a derivative of hydrated pyridine (or dehydrated piperidine) and a GOT (and other pyridoxal-dependent enzymes) inhibitor of this type has not been reported.

In addition to its structural characteristics, the inhibitor shows a unique property in its inhibition specificity, i.e., it inactivated both the PLP and PMP-linked GOT at almost the same rate. None of the inhibitors mentioned and IR spectrum, suggested that gostatin is an amino acid. But the precise structure was difficult to determine from the results of chemical and instrumental analyses and conclusive evidence of the structure was obtained by X-ray crystallographic analysis. The inhibitor contains one asymmetric carbon atom, the carbon at the 5 position. The optical rotation property of gostatin suggested that it is not a mixture of the two possible chiral forms, but its absolute configuration has not yet been established.

Gostatin is a novel heterocyclic amino acid containing one amino and two carboxyl groups. This structure is simply regarded as a derivative of alanine and glutamic acid as follows.

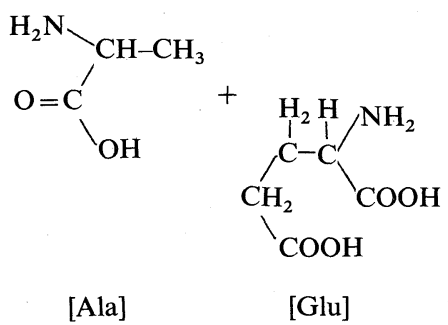

above show the same phenomenon and it is a strange thing for one of these mechanismbased inhibitors.

More detailed investigation of the mechanism of action of gostatin will be published elsewhere.

Acknowledgments. This work was supported in part by a Grant-in-Aid for Scientific Research from the Ministry of Education, Science and Culture of Japan. We are grateful to Dr. Koichi Ibata for X-ray crystallographic study and Mr. H. Nagano for his excellent assistance. Pig heart mitochondrial GOT was generously provided by Professor H. Wada, Osaka University Medical School.

\section{REFERENCES}

1) S. Murao, T. Nishino, N. Katayama and H. Nagano, Agric. Biol. Chem., 45, 1039 (1980).

2) S. Murao and T. Nishino, Agric. Biol. Chem., 47, 1531 (1983).

3) H. Yatzidis, Nature, 186, 79 (1960).

4) Y. Morino, S. Tanase, T. Watanabe, H. Kagamiyama and H. Wada, J. Biochem., 82, 847 
(1977).

5) L. P. Sastchenko, E. S. Severin, D. E. Metzler and R. M. Khomutov, Biochemistry, 10, 4888 (1971).

6) G. T. Cori, B. Illingworth and P. J. Keller, "Methods in Enzymology," Vol. I, ed. by S. P. Colowick and N. O. Kaplan, Academic Press Inc., New York, N. Y., 1955, p. 200.

7) B. M. Shapiro and E. R. Stadtman, "Methods in Enzymology," Vol. 17A, ed. by H. Tabor and C. W. Tabor, Academic Press Inc., New York, N. Y., 1970, p. 910.

8) L. A. Fahien and P. P. Cohen, "Methods in Enzymology," Vol. 17A, ed. by H. Tabor and C. W. Tabor, Academic Press Inc., New York, N. Y., 1970, p. 839.

9) W. B. Jakoby, "Methods in Enzymology," Vol. V, ed. by S. P. Colowick and N. O. Kaplan, Academic Press Inc., New York, N. Y., 1962, p. 770.

10) Z. H. M. Verjee and E. F. Evered, Biochim. Biophys. Acta, 185, 103 (1969).

11) W. T. Jenkins and L. D'Ari, Biochem. Biophys. Res. Commun., 22, 376 (1966).

12) J. B. Stothers, "Carbon-13 NMR Spectroscopy," Academic Press Inc., New York, N. Y., 1972.
13) L. F. Johnson and W. C. Jankowski, "Carbon-13 NMR Spectra," Wiley-Interscience Publication, New York, N. Y., 1972.

14) Y. Asada, K. Tanizawa, T. Nishino, S. Murao and K. Soda, Seikagaku, 53, 845 (1981).

15) C. T. Walsh, Horizons in Biochemistry and Biophysics, 3, 36 (1977).

16) F. Wold, "Methods in Enzymology," Vol. 46, ed. by W. B. Jakoby and M. Wilcheck, Academic Press Inc., New York, N. Y., 1977, p. 3.

17) R. R. Rando, "Methods in Enzymology," Vol. 46, ed. by W. B. Jakoby and M. Wilcheck, Academic Press Inc., New York, N. Y., 1977, pp. 28, 158.

18) T. Toraya, Chemistry (in Japanese), 35, 87 (1980).

19) A. E. Braunstein, "The Enzymes," Vol. IX (3rd ed.), ed. by P. D. Boyer, Academic Press Inc., New York, N. Y., 1973, p. 379.

20) V. L. Florentiev, V. I. Ivanov and M. Y. Karpeisky, "Methods in Enzymology," Vol. 18A, ed. by D. B. McCormick and L. D. Wright, Academic Press Inc., New York, N. Y., 1970, p. 567.

21) K. Soda, K. Tanizawa and N. Esaki, Chemistry (in Japanese), 35, 97 (1980). 